\title{
Effects of Light and Nutrients on Different Germination Phases of the Cosmopolitan Moss Bryum argenteum Hedw. (Bryaceae)
}

\author{
Adaíses Simone Maciel da Silva ${ }^{*}$, Kátia Cavalcanti Pôrto ${ }^{2}$ and Eliana Akie Simabukuro ${ }^{3}$ \\ ${ }^{1}$ Departamento de Fisiologia Vegetal; Universidade Estadual de Campinas; C.P. 6109; 13081-970; Campinas - SP \\ - Brasil. ${ }^{2}$ Departamento de Botânica; Universidade Federal de Pernambuco; 50372-970; Recife - PE - Brasil. \\ ${ }^{3}$ Universidade Federal de São Carlos; Campus Sorocaba; 18043-970; Sorocaba - SP - Brasil
}

\begin{abstract}
The influence of light and nutrients on the different germination phases of Bryum argenteum spores was studied. The following treatments were used: distilled water and nutrient solution under light (12 h) and continuous darkness. The spores germinated when exposed to light, independent of both medium used. Under darkness, the spores swelled and became chlorophyllous. In the presence of nutrient solution, the germination occurred earlier (after two days) when compared to the distilled water (after more than three days). Nutrients were needed to complete the last germination phase in the majority of spores and to provide the protonemal growth.
\end{abstract}

Key words: bryophyte, physiology, germination, protonema, light, nutrients

\section{INTRODUCTION}

Germination and establishment are the more decisive stages of the life cycle of a plant (Harper 1977; Gomes et al., 2006; Socolowski et al., 2008). External signals (e.g. light, temperature, and moisture) can interfere in these processes, promoting or inhibiting the colonization of new sites by spores (bryophytes and ferns), seeds (seedplants) or vegetative diaspores (Schofield, 1985; Kigel and Galili 1995). In bryophytes the dominant phase is haploid and after fertilization, a sporophyte with short life span produces spores, which generally will produce new genetically diverse individuals (Schofield, 1985; Glime, 2007). Spore germination in most mosses of the Bryopsida class is initiated by the spore swelling through water, followed by exospore rupture, cellular distension accompanied by protrusion of the germ tube, and cellular division of protonema (Valanee, 1966; Brandes, 1973; Mogensen, 1978; Nishida, 1978; Nehira, 1983; Schofield, 1985).

The presence of water is a prerequisite for the conversion of stored food reserves into glucose for the production of ATP (Glime, 2007). Nutrients are important for the development of protonema of mosses (Nishida, 1978; Nehira, 1983; 1988; Duckett et al., 2004), but the germination of spores, as a physical process, can occur in nutrient free medium (e.g. distilled water) (Meyer, 1948; Mogensen, 1978; Olesen and Mogensen, 1978). Light may not be essential for the first phase of germination (swelling), but it can be important for the completion of the final phase (cellular division of protonema) given that it is based on energy provided by the phytochrome activity and possibly by photosynthesis (Mohr, 1963; Wada and Kadota, 1989; Hartman and Weber, 1990). For instance,

\footnotetext{
*Author for correspondence: adaisesmaciel@hotmail.com
} 
stored starch breaks down into sucrose in the presence of light (Glime, 2007), while this starch is probably produced from the stored lipids (Monroe, 1968).

The main storage substance in mature spores varies according to the species and can be related to the species habitat (Schofield, 1985). It appears that the species with chlorophyllous spores (short life storage, e.g. starch and protein) inhabit generally mesic habitats, whereas those with achlorophyllous spores (long life storage, e.g. lipid) are mainly found in xeric habitats (Lloyd et al., 1970; Glime, 2007).

Many studies have been carried out on the effect of abiotic factors on the spore germination of bryophytes (Meyer, 1848; Krupa, 1964; Mitra et al., 1965; Egunyomi, 1978; Mehta, 1988; Wiklund and Rydin, 2004), but few have identified which phases of germination are affected by these factors (Valanne, 1966; Monroe, 1968; Mogensen 1978). In order to find out what spore germination phases are influenced by an abiotic factor, it is important to understand how the germination and the subsequent establishment of bryophyte species are controlled. Therefore, a weed species was chosen as a model to investigate the influence of light and nutrients on the different germination phases of the spores.

Bryum argenteum Hedw. (Bryaceae) is a common moss, which has numerous spores per capsule. In addition, its spores are yellow and have many oil droplets. $B$. argenteum is a cosmopolitan moss that generally colonizes rocks, soil, and man-made substrates of open habitats, forming populations that persist for a few years (Ochi, 1980; Miles and Longton, 1992). Two questions were investigated: (1) Was light needed for the last phase of germination - protrusion of the germ tube and subsequent cellular division of the protonema? (2) Were nutrients dispensable for the germination and the first days of protonemal growth?

It was hypothesized that the spores of $B$. argenteum needed light to germinate, given that this species is commonly found in open and perturbed sites. On the other hand, they did not require nutrients for the germination and early protonema growth, because they were rich in oil droplets (lipid storage).

\section{MATERIALS AND METHODS}

Individuals of $B$. argenteum were collected in October 2003 from different sporophytic populations on man-made substrates in border of forest of the Municipal Ecologic Reserve of Bonito, Pernambuco, Brazil (Mata da Reserva Ecológica Municipal de Bonito-PE; 08³0'S and $\left.35^{\circ} 43^{\prime} \mathrm{W}\right)$. The site is an Atlantic Forest remnant approximately $750 \mathrm{~m}$ above sea level, with average rainfall of $1,157 \mathrm{~mm}$ per year and a mean annual temperature of $21.5^{\circ} \mathrm{C}$ (Santiago et al., 2004). Samples containing mature, closed capsules were used in the experiments. Sporophytes were separated from the gametophytes and sterilized in $1.5 \%$ sodium hypochlorite for two minutes and washed in sterile distilled water (Duckett et al., 2004). Spores from approximately 40 capsules were homogenized and distributed among the following treatments: distilled water and nutrient solution under light and continuous darkness. Three replicates were used per treatment.

The Erlenmeyer flasks $(100 \mathrm{~mL})$ containing $25 \mathrm{~mL}$ distilled water or nutrient solution $\left[\mathrm{MgSO}_{4} \cdot 7 \mathrm{H}_{2} \mathrm{O}\right.$ $510 \mathrm{mg} \mathrm{L}^{-1} ; \mathrm{KNO}_{3} 120 \mathrm{mg} \mathrm{L}{ }^{-1} ; \mathrm{Ca}\left(\mathrm{NO}_{3}\right)_{2} \cdot 4 \mathrm{H}_{2} \mathrm{O}$ $1440 \mathrm{mg} \mathrm{L}{ }^{-1} ; \mathrm{KH}_{2} \mathrm{PO}_{4} 250 \mathrm{mg} \mathrm{L}^{-1}$; iron solution 1 $\mathrm{mL} \mathrm{L}^{-1}\left(\mathrm{Na}_{2}\right.$ EDTA 33,2 $\mathrm{g} \mathrm{L}^{-1}$; $\mathrm{NaOH} 3,65 \mathrm{~g} \mathrm{~L}^{-1}$; $\mathrm{FeSO}_{4} \cdot 7 \mathrm{H}_{2} \mathrm{O} \quad 25 \mathrm{~g} \mathrm{~L}^{-1}$ )] (Dyer, 1979), plus fungicide nistatine $\left(100 \mathrm{U} \mathrm{mL}^{-1}\right)$ were used. All the flasks were covered with gauze and plastic film to avoid the medium's evaporation and contamination. To eliminate the previous contamination, glassware, nutrient solution and distilled water were autoclaved at $120{ }^{\circ} \mathrm{C}$ for 20 minutes.

The flasks were incubated under a $12 \mathrm{~h}$ photoperiod and continuous darkness (using three black plastic bags) at $25 \pm 1^{\circ} \mathrm{C}$ and light intensity of approximately $20 \mu \mathrm{mol} \mathrm{m} \mathrm{m}^{-2}$.

Spore counting was carried out daily under an optical microscope and the spores were classified in the following categories: achlorophyllous (unswollen), chlorophyllous (swollen), ruptured exospore, and germinated (protrusion of germ tube, or protonema with one or more cells) (Fig. 1). Two sub-samples were daily taken from each replicate and mounted on the slide and cover slip. Sub-samples of the spores were taken from the surface of the solution. One hundred spores were randomly examined in each slide.

The germination values were expressed as a percentage in the text and transformed in ArcSin 
$\sqrt{ }(\% / 100)$ for statistical analysis. Mean germination time was calculated according to the equation $=\sum(\mathrm{tn}) / \sum \mathrm{n}$, where $t$ was time in days from day 0 , and $n$ was the number of spores that started germination from day $t$ (Labouriau, 1983). The Mann-Whitney test $(\alpha=0.05)$ was used for the comparison of the germination percentage and mean germination time between the treatments. Analyses were carried out using the statistical software Bioestat 3.0 (Ayres et al., 2003).

\section{RESULTS}

The spores of $B$. argenteum were positively photoblastic, i.e. they only germinated when exposed to light, regardless of the medium used (Fig. 2). However, all the spores kept in continuous darkness were swollen and chlorophyllous, indicating that oil droplets were probably broken in another storage product. Many spores kept in darkness over 14 days germinated after exposure to light (ca. 90 to $100 \%$ in all replicates).

Transition from the unswollen spores to the subsequent phases occurred gradually under the light. In the nutrient solution, the rupture of exospore and germination occurred earlier (rupture after one day and germination after two days) in comparison to the distilled water (rupture after three days and germination after more than three days) (Fig. 2 and $3 \mathrm{~A}$ and $\mathrm{C}$ ).
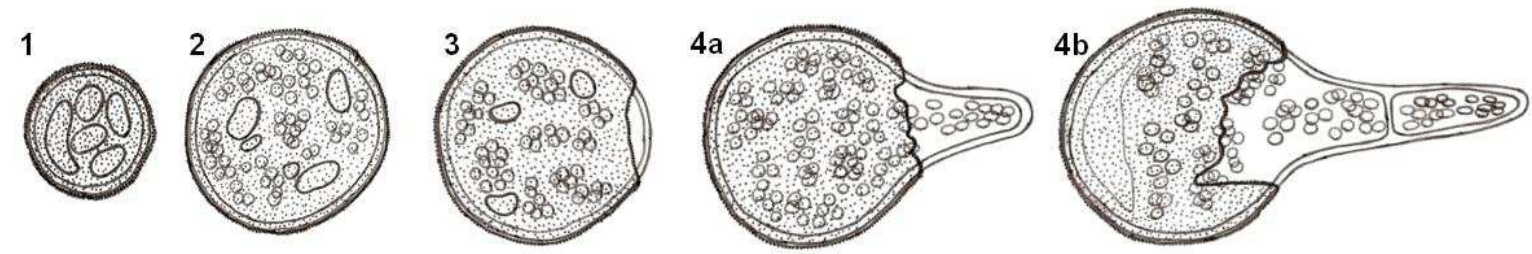

Figure 1 - Phases of spores from dispersal to germination. 1. unswollen spore, 2. swollen spore, 3. ruptured exospore, $4 \mathrm{a}$. protrusion of germ tube and 4b. protonema.
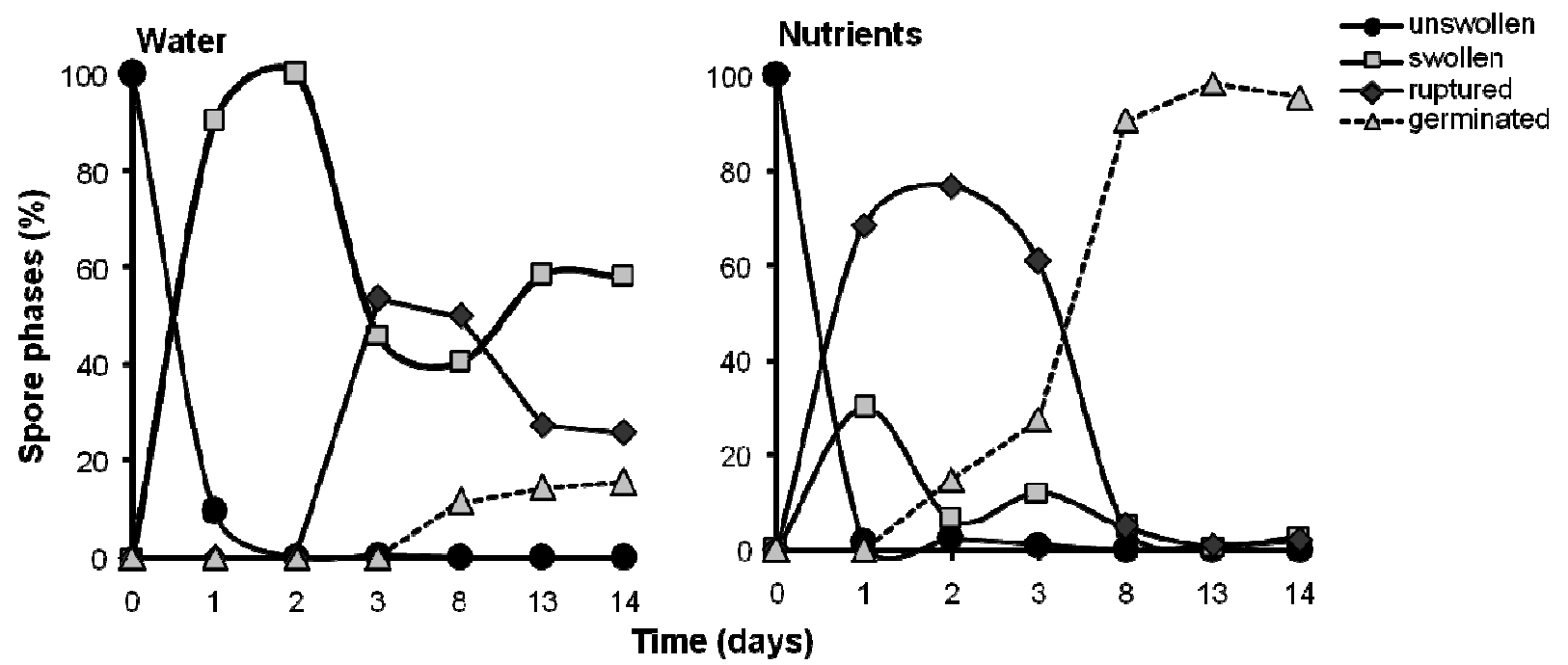

Figure 2 - Percentage of spores in different phases of Bryum argenteum after fourteen days in distilled water and nutrient solution at $12 \mathrm{~h}$ photoperiod and $25^{\circ} \mathrm{C}$. Symbols indicate daily means from three replicates. 
The spores germinated in distilled water had stabilized in the "germ tube" phase by the $14^{\text {th }}$ day with many cells collapsed, while the spores kept in the nutrient solution produced protonemata with about ten cells during this same period (Fig. 3B and D). In the nutrient solution, the final germination percentage was higher than in water (nutrients: $98.3 \% \pm 1.50$ and water: $15.5 \% \pm$ 4.84; $\mathrm{Z}=2.88, \mathrm{p}=0.004)$, whereas the mean germination time of spores cultured in water was higher than in nutrient solution, indicating a delay in the germination under this treatment (water:11.98 days \pm 1.31 and nutrient: 9.15 days \pm $0.61 ; \mathrm{Z}=2.80, \mathrm{p}=0.005$ ).

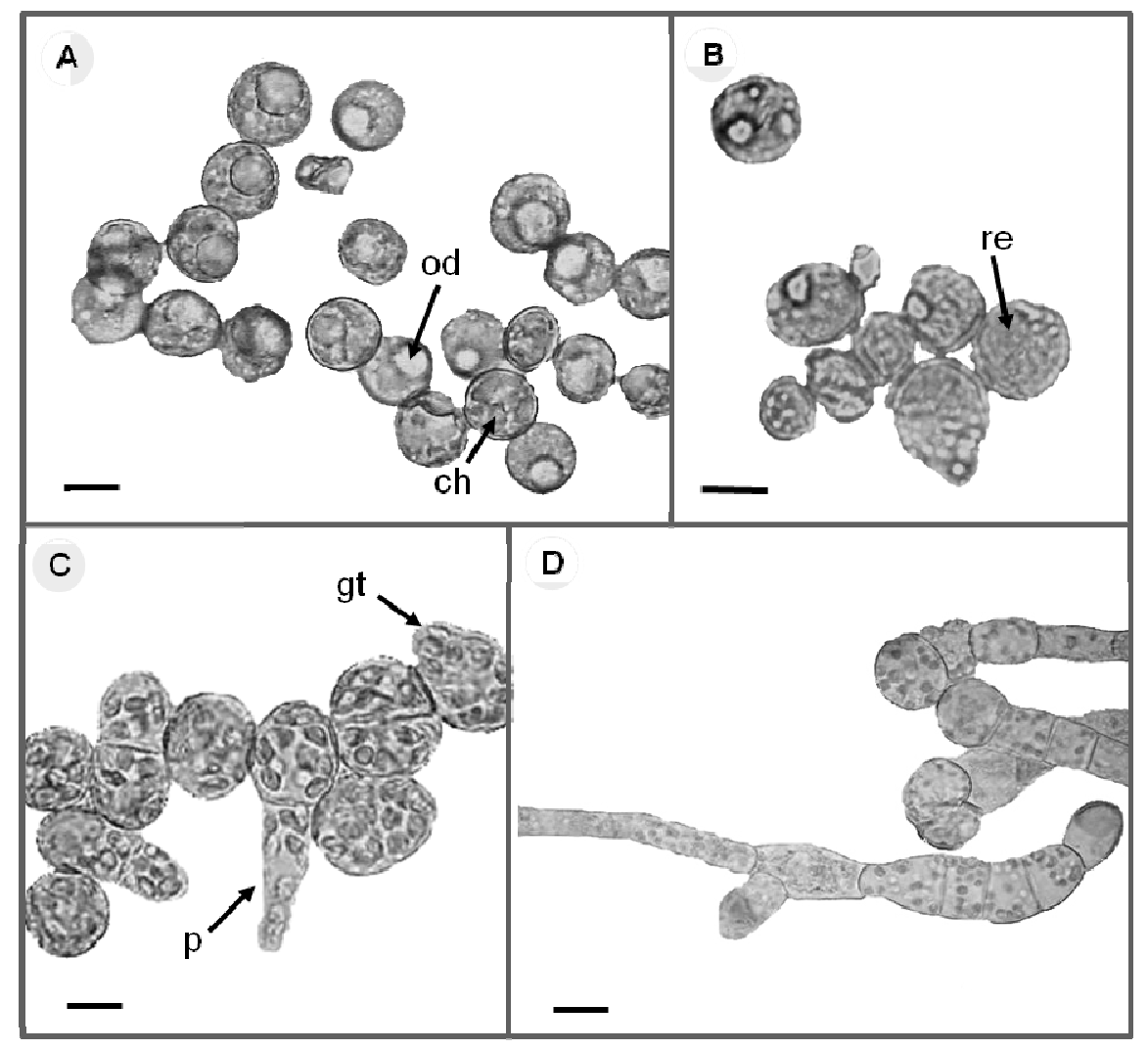

Figure 3 - Spore germination of Bryum argenteum cultured in distilled water $(A=3 d, B=14 d)$ and nutrient solution $(\mathrm{C}=3 \mathrm{~d}, \mathrm{D}=14 \mathrm{~d})$, at $12 \mathrm{~h}$ photoperiod and $25^{\circ} \mathrm{C}$. od. oil droplet, ch. chloroplast, re. ruptured exospore, gt. germ tube and p. one-celled protonema. Scar bar $=10$ $\mu \mathrm{m}$.

\section{DISCUSSION}

Spores of $B$. argenteum required light to germinate, given that in darkness there was only swelling, while in light, all the germination phases occurred. Nutrients were needed to complete the last germination phase in the majority of spores and to provide the protonemal growth. In water, a few spores reached the "protrusion of germ tube" phase. The absence of germinating spores of $B$. argenteum under darkness, although with swelling spores, seemed to be related to the requirement for a light signal probably mediated by phytochromes (Cove and Lamparter, 1998; Cove et al., 2006), as was observed in the mosses Funaria hygrometrica Hedw. (Krupa, 1964; Monroe, 1968), Ceratodon purpureus (Hedw.) Brid. (Valanee, 1966), Octoblepharum albidum Hedw. (Eguniomy, 1978) and Physcomitrella patens (Hedw.) Bruch and Schimp. (Schaefer and Zryd, 2001; Cove et al., 2006). In bryophytes, responses such as spore germination, tip growth and cell division are phytochrome-dependent (Wada and Kadota, 1989; Suetsugu and Wada, 2007). Glime (2007) hypothesized three potential metabolic pathways for energy supply during spore germination: 1) stimulation of phytochrome, which initiated the conversion of starch in sugar preceding the 
production of chlorophyll, possibly under the control of the gibberellic acid; 2) conversion of fatty acids in sugar, providing energy for the production of chlorophyll; 3) green spore photosynthesis in the presence of light. Spores of $B$. argenteum are not chlorophyllous but they have oil droplets, and they possibly initiate the germination using one or more of the pathways (maybe 1 and 2) proposed by Glime (2007).

Spores of most bryophytes have chlorophyll and oil spherules when mature (Schofield, 1985). Species with green spores are much more frequent than the species having spores with reduced chloroplast structure, and, thus also a reduced green color. Reductions in chloroplast structure and quantity of chlorophyll may indicate a decrease in the physiological activity of the spores (Mogensen, 1983). The chloroplasts observed in the spores of $B$. argenteum when cultured under absolute darkness were possibly produced from the storages, or, less probably, they were already present in the dry spore but hidden below the exospore.

Spores of bryophytes cultured in darkness on an organic medium (e.g. sucrose addition) were able to reach germination because sucrose substituted the energy provided by light (Valanee, 1966; Monroe, 1968). This signifies that any growth following swelling will necessarily require energy (Glime, 2007), i.e. all the phases after the swelling of the spore need light or another energy source as sucrose.

Furthermore, although bryophytes are considered shade plants because they have a light compensation point and ratio of chlorophyll $(\mathrm{a} / \mathrm{b})$ smaller than the angiosperms (Rastorfer, 1970; Marschall and Proctor, 2004), B. argenteum is a moss with colonist characteristics, colonizing open and exposed environments, such as brightly lit habitats (Miles and Longton, 1992). Blocking the germination process until minimum light conditions are offered, is an important strategy for the success of the establishment. This insures that spores will not germinate under soil or elsewhere where they will never find light (Glime, 2007).

The final germination phases (germ tube and protonema) of $B$. argenteum spores require nutrients, possibly indicating the exhaustion of spore storage substances. Furthermore, although water, light and temperature are requisites for primary control over the germination of spores, it is probable that individual species show specific requirements which narrow the window of germination and help in the detection of favorable micro-sites with low competition. These controls can comprise nutrients, $\mathrm{pH}$, photoperiod and exogenous substances (Grime et al., 1981; Hölzel and Otte, 2004; Glime, 2007). For instance, the weed moss species Funaria hygrometrica is known to show better spore germination and protonemal growth on soil from burned areas, which are phosphate-nitrate enriched (Hoffman, 1966; Esposito et al, 1999).

Nitrate is the major naturally occurring inorganic soil component that stimulates seed and fern spore germination (Hilhorst and Karssen, 1992). For instance, nitrate-dependent seeds are lightrequiring, and this positive interaction between the light and nitrate is the principal limitation to germination. This interactive effect of light and nitrate on germination has been demonstrated in many weed species (Hilhorst and Karssen, 1992). This mechanism makes it possible that (nondormant) seeds will only germinate when the combination of phytochrome-red and nitrate levels are adequate. An explanation for the sensing mechanism is the ability of seeds to detect local disturbances of light and nitrate levels in the immediate environment (Pons, 1992).

It could be possible that the spores of $B$. argenteum, after dispersal, even when found optimal moisture and light, could not complete the germination due to nutrient requirements (probably nitrate). However, this question would be best exploited using more bryophyte species with spores bearing or non-chlorophyll, as models, to test the actual influence of nutrient sources such as nitrate, ammonium and phosphate on spore germination. On the other hand, it could be possible that the limitations of light and nutrients on the spore germination and the growth of the initial protonema of $B$. argenteum might guarantee the establishment of new populations only on substrates free from other plants and rich in these resources.

\section{ACKNOWLEDGEMENTS}

We thank Adalberto José dos Santos and two anonymous reviewers for useful comments on the manuscript and André Ferreira Novaes for his valuable help in data collection. This study was carried out in the Universidade Federal de Pernambuco, Brazil (Laboratório de Fisiologia Vegetal). 


\section{RESUMO}

Neste estudo procuramos avaliar a importância de fatores abióticos sobre a germinação de esporos e o desenvolvimento do protonema de musgos. Para isso, nós analisamos o efeito da disponibilidade de luz e nutrientes sobre diferentes fases da germinação de esporos de um musgo amplamente distribuído. Bryum argenteum geralmente apresenta muitos esporos por cápsula, e estes são amarelos devido à presença de muitos corpúsculos lipídicos. Foram usados os tratamentos: água destilada e solução nutritiva sob luz $(12 \mathrm{~h})$ e escuro contínuo. Os esporos mostraram-se fotoblásticos positivos, ou seja, apenas germinaram sob luz, independentemente do meio utilizado. Sob escuro os esporos apenas embeberam, tornando-se clorofilados provavelmente a partir da quebra de reservas. Em solução nutritiva a germinação ocorreu mais rapidamente (dois dias) em relação à água destilada (mais de três dias após cultivo). No entanto, os nutrientes foram necessários para completar a última fase da germinação da maioria dos esporos.

\section{REFERENCES}

Ayres, M.; Ayres-Junior, M.; Ayres, D.L. and Santos, A.S. (2003), BioEstat - Versão 3.0. Belém: Sociedade Civil Mamirauá.

Brandes, H. (1973), Gametophyte in ferns and development bryophytes. Review of Plant Physiology, 24, 115-28.

Cove, D.J.; Bezanilla, M.; Harries, P. and Quatrano, R. (2006), Mosses as model systems for the study of metabolism and development. Annual of Review of Plant Biology, 57, 497-520.

Cove, D. and Lamparter, T. (1998), The role of light in the regulation of moss development. In - Microbial Responses to Light and Time, eds. M.X. Caddick, D.A. Hodgson and M.K. Phillips-Jones. Series: Society for General Microbiology Symposia, 56, 125141.

Duckett, J.G.; Burch, J.; Fletcher, P.W.; Matcham, H.W.; Read, D.J.; Russell, A. and Pressel, S. (2004), In vitro cultivation of bryophytes: a review of practicality, problems, progress and promise. Journal of Bryology, 26, 3-20.

Dyer, A.F. (1979), The culture of fern gametophytes for experimental investigation. In - The experimental biology of ferns. ed. A.F. Dyer. Academic Press, London. pp. 253-305.
Egunyomi, A. (1978), Comparative culture studies on the spores and gemmae of Octoblepharum albidum Hedw. Journal of Hattori Botanical Laboratory, 44, 25-30.

Esposito, A.; Mazzoleni, S. and Strumia S. (1999), Post-Fire Bryophyte Dynamics in Mediterranean. Vegetation. Journal of Vegetation Science, 10, 261268.

Glime, J.M. (2007), Bryophyte Ecology. Volume 1. Physiological Ecology. Ebook sponsored by Michigan Technological University and the International Association of Bryologists. Accessed on Mar 2008 at <http://www.bryoecol.mtu.edu/>.

Gomes, G.S.; Randi, A.M.; Puchalski, A.; Santos, D.S. and Reis, M.S. (2006), Variability in the germination of spores among and within natural populations of the endangered tree fern Dicksonia sellowiana Hook. (Xaxim). Brazilian Archives of Biology and Technology 49:1-10.

Grime, J. P.; Mason, G.; Curtis, A.V. ; Rodman, J.; Band, S. R.; Mowforth, M. A.G.; Neal, A.M. and Shaw, S. (1981), A comparative study of germination characteristics in a local flora. Journal of Ecology, 69, 1017-1059.

Harper, J.L. (1977), Population biology of plants. London and New York, Academic Press.

Hartman, E. and Weber, M. (1990). Photomodulation of protonema development. In - Bryophyte development: Physioloy and Biochemistry, eds. R.N. Chopra and S.C. Bhatla. Flórida, CRC. Press, pp. 33-54.

Hilhorst, H.W.M. and Karssen, C.M. (1992), Effect of Chemical Environment on Seed Germination. In The ecology of regeneration in plant communities, ed. M. Fenner. Wallingford, C.A.B. International, pp. 293-310.

Hoffman, G.R. (1966), Ecological Studies of Funaria hygrometrica Hedw. in Eastern Washington and Northern Idaho. Ecological Monographs 36: 157180.

Hölzel, N. and Otte, A. (2004), Ecological significance of seed germination characteristics in flood-meadow species. Flora 199, 12-24.

Kigel, J. and Galili, G. (1995), Seed development and germination. New York, Marcel Decker.

Krupa, J. (1964), Studies on the physiology of germination of spores of Funaria hygrometrica (Sibth). Acta Societatis Botanicorum polaniae, 33, 179-192.

Labouriau L.G. (1983), A Germinação das sementes. Washington,Secretaria Geral da Organização dos Estados Americanos.

Lloyd, R.M. and Klekowiski Jr., E.J. (1970), Spore germination and viability in pteridophyta: evolutionary significance of chlorophyllous spores. Biotropica, 2, 129-137. 
Marschall, M. and Proctor, M. (2004), Are Bryophytes Shade Plants? Photosynthetic Light Responses and Proportions of Chlorophyll a, Chlorophyll b and Total Carotenoids. Annals of Botany, 94, 593-603.

Mehta, P. (1988), In vitro studies on spores germination, protonemal differentiation and bud formation in three mosses grown in vitro. Journal Hattori Botanical Laboratory, 64, 401-410.

Meyer, S.L. (1948), Physiological studies on mosses. vii. Observations on the influence of light on spore germination and protonema development in Physcomitrium turbinatum and Funaria hygrometrica. The Bryologist, 51, 213-217.

Miles, C.J. and Longton, R.E. (1992), Deposition of moss spores in relation to distance from parent gametophytes. Journal of Bryology, 17, 355-368.

Mitra, G.C.; Misra, L.P. and Prabha, C. (1965), Interaction of red and blue light on the development of the protonema and bud formation in Pohlia nutans. Planta, 65, 42-48

Mogensen, G.S. (1978), Spore development and germination in Cinclidium Sw. (Mniaceae Mitt., Bryophyta), with special reference to spore mortality and false anisospory. Canadian Journal of Botany, 56, 1032-1060.

Mogensen, G.S. (1983), The spore. Reproductive Biology. In - New Manual of Bryology, vol 1. ed. R.M. Schuster. The Hattori Botanical Laboratory, Nichinan, pp. 325-342.

Mohr, H. (1963), The influence of visible radiation on the germination of archegoniate spores and the growth of the fern protonema Journal of the Linnean Society, 58, 287-296.

Monroe, J.H. (1968), Light- and electron-microscopic observations on spore germination in Funaria hygrometrica. Botanical Gazette, 129, 247-258.

Nehira, K. (1983), Spore germination, protonema development and sporeling development. In - New Manual of Bryology. vol. 1, ed. R.M. Schuster. Nichinan, The Hattori Laboratory, pp. 343-379.

Nehira, K. (1988), Germination and protonema. In Methods in Bryology, ed. J.M. Glime, Nichinan, Hattori Botanical Laboratory, pp. 113-117.

Nishida, Y. (1978), Studies on the sporeling types in mosses. Journal of Hattori Botanical Laboratory, 44, $371-454$.

Ochi, H. (1980), A revision of the neotropical Bryoideae, Musci (First part). The Journal of the Faculty of Education Tottori University, 29, 49-154.
Olesen, P. and Mogensen, G.S. (1978), Ultrastructure, Histochemistry and Notes on Germination Stages of spores in Selected Mosses. The Bryologist, 81, 493516.

Pons, T.L. (1992), Seed responses to light. In - The ecology of regeneration in plant communities, ed. M. Fenner, Wallingford, C.A.B. International, pp. 237260.

Rastorfer, J.R. (1970), Effects of light intensity and temperature on photosynthesis and respiration of two East Antarctic Mosses, Bryum argenteum and Bryum antarcticum. The Bryologist, 73, 544-556.

Santiago, A.S.P.; Barros, I.C.L. and Sylvestre, L.S. (2004), Pteridófitas ocorrentes em três fragmentos florestais de um brejo de altitude (Bonito, Pernambuco, Brasil). Acta Botanica Brasilica, 18, 781-792.

Schaefer, D.G. and Zryd, J-P. (2001), The Moss Physcomitrella patens, Now and Then. Plant Physiology, 127, 1430-1438.

Schofield, W.B. (1985), Introduction to Bryology. New York, Macmillan Publishing Company.

Socolowski, F.; Vieira, D.C.M. and Takaki, M. (2008), Interaction of temperature and light on seed germination in Tecoma stans L. Juss. ex Kunth (Bignoniaceae). Brazilian Archives of Biology and Technology 51, :523-530.

Suetsugu, N. and Wada, M. (2007), Phytochromedependent Photomovement Responses Mediated by Phototropin Family Proteins in Cryptogam Plants. Photochemistry and Photobiology, 83, 87-93.

Valanee, N. (1966), The germination phases of moss spores and their control by light. Annales Botanici Fennici, 3, 1-60.

Wada, M. and Kadota, A. (1989), Photomorphogenesis in lower green plants. Annuals Review of Plant Physiology and Plant Molecular and Bioliology, 40, 169-91.

Wiklund, K. and Rydin, H. (2004), Ecophysiological constraints on spore establishment in bryophytes. Functional Ecology, 18, 907-913.

Received: September 02, 2008; Revised: April 14, 2009; Accepted: October 21, 2009. 